\title{
THE INTEGRATION OF PROJECT-BASED LEARNING (PBL) IN EDUCATION 4.0 TOWARD EFL STUDENTS' ACTIVITIES
}

\author{
Helsa Gita Almaida ${ }^{1}$ \& Alan Jaelani ${ }^{2}$ \\ English Education Program \\ Faculty of Teacher Training and Education \\ Universitas Ibn Khaldun, Bogor \\ gitacuzt@gmail.com¹; alan.jaelani@uika-bogor.ac.id ${ }^{2}$
}

\begin{abstract}
This research aims to realize the implementation and integrated project-based learning (PBL) activities in education 4.0 towards EFL students' activities. This study uses qualitative methods as a framework for analyzing and collecting data. The data were obtained from observations and interviews. The results showed that the use of Google Classroom, Comic Page Creator, and Learning Apps can complement projects in the EFL class; the use of Google Classroom, Comic Page Creator, and Learning Apps can help students access the material and complete the Project; and most students integrating PBL into Education 4.0 can improve their English language skills.
\end{abstract}

Keywords: Project-Based Learning, Education 4.0, EFL

\section{INTRODUCTION}

Project-Based Learning (PBL) is a teaching method in which students acquire applying skills by working on long-term projects that involve in-depth investigation of a topic or question (Smith, 2018). Besides, according to Thomas (2000) PBL is defined as a learning model that provides students with opportunities to learn by doing projects. This is a learning method in the form of this project which provides an opportunity for students to be the center of the learning process. PBL is an approach for students to learn, students pursue knowledge by asking questions that have aroused their natural curiosity (Bell, 2010). PBL is a type of contextualized cooperative learning designed within four phases in the implementation of PBL (S. R. Tamim, 2013). The stages start with the preparation project, realization project, presentation project, evaluation project. Indirectly, the use of PBL also encourages students to master the knowledge needed to complete the project well. This knowledge can be in the form of results which are then used to be presented. These results are obtained through logical, critical, and systematic thinking.

Likewise, in the learning process, teachers need various techniques to be accepted because not all EFL students can participate in learning on a project. Therefore, another way is needed to actualize these learning outcomes by keeping up with the times in education 4.0. Education 4.0 is a response to the need of IR 4.0 where people and technology are aligned to enable new things in learning. Education 4.0 is a response to the needs of IR 4.0 where humans and technology are aligned to enable new things in learning.

Learning concept in this era is related to the rapid development of technology. Its application to teaching comes into full play in education (Jaelani, Alan and Sutari, Dilla R., 2020). According to Huan \& Chea (2019) Education 4.0 is a new trend in education now where students are equipped with ICT and collaborative skills, creative, critical thinking, communicative, and 
interested in lifelong learning to support IR. 4.0. It means that the learning process is not only reading and writing, but also the learning process can increase students' creativity in learning English according to the times. According to Sinlarat (2016) the learning management of this era is a new learning system which allows students to learn to grow with knowledge and skills for a lifetime, not only knowing how to read and write.

Based on the above issue, Education 4.0 is very likely to have collaborated with project-based learning. Thus, all learning outcomes in EFL classrooms are expected to be realized through the implementation of PBL in education 4.0. These learning outcomes contain students' activities in EFL classrooms. The integration of PBL in Education 4.0 is thought to be able to increase the activities of EFL students in the learning process.

Previous research has shown that implementing project-based learning (PBL) with information and communication technology (ICT) in a Rural School: an EFL Context. Students can experience more interesting and meaningful learning in PBL English classes. The use of technology in based Project Based Learning (PBL) can increase students' motivation, interest, and creativity in English language classes (Shanti, 2019). Meanwhile Anggraeni (2018) found challenges for English teachers and students in implementing Education 4.0 which focuses on innovation and maximizing the use of information, the internet, and technology in the English class. However, this study explores more about PBL integration in Education 4.0 towards EFL student activities.

This research aims to realize the implementation and integrated projectbased learning (PBL) in education 4.0 towards EFL students' activities.

\section{METHOD}

This research uses qualitative methods and uses a case study research design. Besides, Creswell (2010: 4), qualitative research is method to explore and understand the meaning that some individuals or groups of people think come from social or humanitarian problems. Therefore, a case study is a qualitative research approach that is used to understand an issue or problem using a case (Creswell, 2014: 135). The researchers intentionally chose the Porong Sidoarjo secondary school area because the researchers knew that students had used technology to complete the project, and the researchers wanted to express students' activities in completing English project using Education 4.0. The participants of this study were students from grade $9^{\text {th }}$. The instrument used for gathering information was the observation and interview. The researchers could observe the conditions of student interaction in learning English by using several applications such as Learning Apps, Comic Page Creator, and Google Classroom. In this observation, the researchers used Google Classroom and WhatsApp groups to retrieve data. Observation aims to get observation aims to know the implementation and integrated project-based learning (PBL) in education 4.0 towards EFL students' activities in the learning process. Furthermore, the interview is conducted to get more information from the students about integration of projectbased learning (PBL) in education 4.0 toward EFL students' activities. Before conducting the interview, the researchers took samples of 5 participants from grade $9^{\text {th }}$. In this interview the researchers gave 5 questions related to English projects such as writing, speaking, and reading with answers in the form of participants' opinions. 


\section{FINDING AND DISCUSSION}

This section relates the learning activities of EFL students in integrating PBL in education 4.0. These activities can be seen from the results of student observations and interviews.
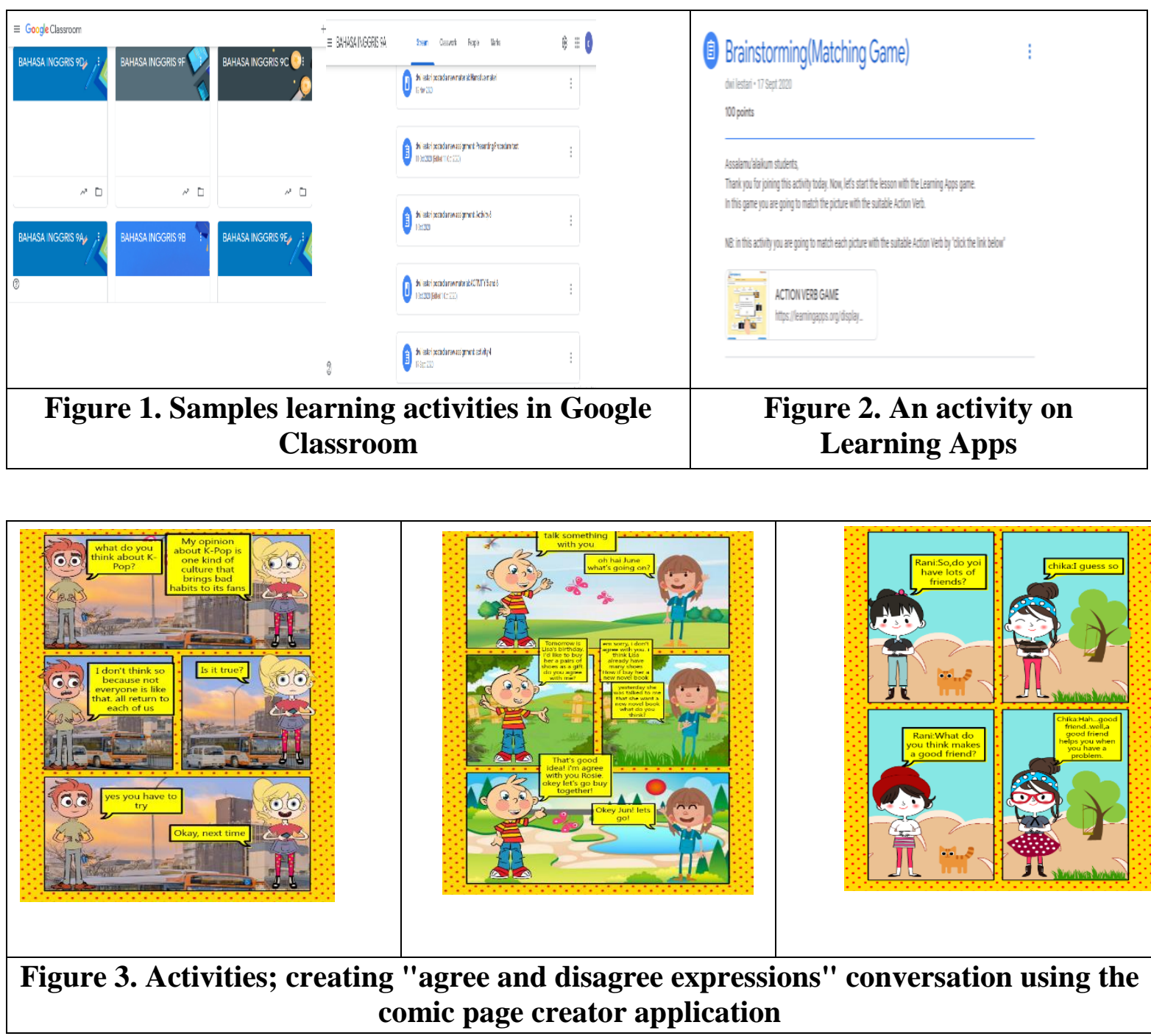

This research was conducted by student observation activities in learning English in the form of projects carried out independently during online learning. In addition, class hours and learning activities are carried out during class hours. The Google Classroom Platform (GC), a social learning platform, is used to accommodate course content, assignments, and fees. Figure 1 is a learning activity in using GC to show the course project interface on the platform (GC), while Figure 2 is an observation activity by the researchers. The student's activities were instructed in Google classroom to complete the game in the learning application (https://learningapps.org/display? $\mathrm{v}=\mathrm{pht} 1$ 7at6220). Besides, Figure 3 shows the results of the project of students who have conversations in English on agree and disagree material. In this case, students created and designed stories such as comics. In the comics, there were expressions of agreement and disagreement. In making comic stories, students use the Comic Page Creator application. In addition, every conversation conducted by students should not be the same as their peers. 
The results of observations above were also supported by some statements from the result of the interview that in some questions below;

Q-1 : Does the integration of PBL in Education 4.0 help you in learning English?

Tell me the reason!

P-2: "Yes, because it can easily complete the English language project."

P-4: "Yes, because I can complete my English project anytime and anywhere."

P-5: "Yes, because I can learn by using the application when working on an English project."

Q-3: Does the integration of PBL in Education 4.0 improve your English skill? Tell me the reason why!

P-2: "Yes, because it can motivate me to learn English, especially in writing."

P-3: "Yes, because it can help me to know some of the vocabulary provided in the learning apps."

P-5: "Yes, because it can increase my interest in learning English by using the application."

From these results, the researchers found that student activities in projectbased English learning using EFL classroom applications had a positive impact on improving their English skills. In addition to project-based English learning using applications, most students agreed that the integration of PBL in Education 4.0 was useful and had a major influence on their English creativity. These findings correlate with (Shanti, 2019) that the use of technology in project-based learning (PBL) can increase students' motivation, interest, and creativity in the English classroom. This perception is supported by Anggraeni (2018) who found challenges for English teachers and students in implementing Education 4.0 which focuses on innovation and maximizing the use of information, the internet, and technology in the English class. Therefore students prefer to be in the middle of the educational process. In addition, they are satisfied with the idea that turning traditional practices into more autonomous learning meets their needs and incorporates new technologies in the classroom.

\section{CONCLUSION}

Based on the results of the study, most students have positive attitudes towards the integration of Project-Based Learning (PBL) in Education 4.0 in the EFL class. The students are able to participate actively in the process of building knowledge and skills activities. It indicates that students could use applications to access material and complete English projects easily. The results also show that integrating PBL in Education 4.0 can help students improve their learning abilities inside and outside the classroom because they can easily get learning material anywhere and anytime. This study reveals that most students felt that the integration of Project-Based Learning (PBL) in Education 4.0 is able to improve students' English skills.

\section{REFERENCES}

Alsowat, H. (2016). An EFL Flipped Classroom Teaching Model: Effects on English. Journal of Education and Practice, 108-121.

Anggraeni, C. W. (2018). Promoting Education 4.0 in English for Survival Class: What are. Journal of English Language, Literature, and Teaching, 12-24.

Bell, S. (2010). Project-Based-Learning for 21st Century: skill for the future. The Clearing House, 3943.

Creswell, J. W. (2014). Research Design: Qualitative, Quantitative and Mixed Methods Approaches (4th ed. California: Sage Publication.

Dunwill, E. (2016). 4 changes that will shape the classroom of the future: Making education fully 
technological. Retrieved from https://elearningindustry.com/4changes-will-shape-classroom-ofthe-future-making-educationfully-technological.

Jaelani, Alan \& Sutari, Dilla R. (2020). Students' Perception of Using Duolingo Application as a Media in Learning Vocabulary. Bogor English Student and Teacher (BEST) conference 2020, 40-47

S. R. Tamim, a. M. (2013). Definitions and Uses: Case Study of Teachers Implementing Project-based Learning. Interdisciplinary Journal of Problem-Based Learning, 7(2).

Shanti, Y. \&. (2019). ICT and ProjectBased Learning in a Rural School. Journal of Advances in Social Science, Education and Humanities Research, 29-35.

Sinlarat.P. (2016). Education 4.0 is More than Education. Annual Academic. Bangkok: The Secretariat Office of Teacher's Council.

Smith, A. (2018). Project-Based Learning Made Simple. United State: Ulysses Press. 